||||||||||||||||||||||||||||||||||||||

\section{研究論文}

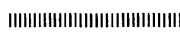

\title{
パルス加圧排気鋳造法による $\mathrm{Al}_{2} \mathrm{O}_{3}$ 粒子 $/ 6061$ アルミニウム合金複合材料の作製*
}

\author{
武高輝 $* *$. 河野 紀雄*** \\ 高橋 恒夫林・渡辺 久藤 $* * *$
}

Fabrication of $\mathrm{Al}_{2} \mathrm{O}_{3} / 6061$ particles composite

materials by pulse squeeze exhaust casting

\author{
Gaohui WU**, Norio KOUNO*** \\ Tuneo TAKAHASI ${ }^{* * *}$ and Hisahuji WATANABE***
}

\begin{abstract}
The fabrication process named as pulse squeeze exhaust casting was developed. In comparison with the squeeze exhaust casting the process was characterized by controlling the press applied the molten metal in the manner of pulse, so that the air in the preform was fully exhausted. By this process the 6061 aluminum alloy composites containing $\mathrm{Al}_{2} \mathrm{O}_{3}$ particles of $0.15 \mu \mathrm{m}$ diameter have been successfully fabricated. The tensile strengths of samples with $30 \mathrm{vol} \% \mathrm{Al}_{2} \mathrm{O}_{3} \mathrm{par}-$ ticles were $500 \mathrm{MPa}$ in the as-cast and $637 \mathrm{MPa}$ in the extruded conditions, and the elongation of extruded one were $8 \%$ at room temperature and $32 \%$ at $200^{\circ} \mathrm{C}$, respectively.
\end{abstract}

Keywords: pulse squeeze exhaust casting, composite material, $\mathrm{Al}_{2} \mathrm{O}_{3}$ particle, $\mathrm{Al}_{2} \mathrm{O}_{3} / 6061$, tensile strength

(Received October 19, 1993)

\section{1. 緒言}

粒子強化拉よび短瀻維強化金属基複合材料の複合方法 のうち, 加圧鋳造法は複合に要する時間が短く, 鋳造に よる成形性がよく，生産性に優れているなどの利点があ る1),2)。しかし加圧鋳造の際，しばしばプリフォーム中 に存在した空気が圧縮されたまま複合材料の中に残り， 材質汇悪い影響を与えるといら久点があると考えられて いる。

また一般に, 粒子強化複合材料の粒子径が小さいほど 強度が高くなるが3)，粒子径が小さくなるとともに同一 体積率で粒子の表面積が大きくなり, 粒子間の間隙も小 さくなり，溶湯の流動抵抗が大となる。このため，加圧 鋳造法による複合化は比較的難しくなり, 特に, 粒子径 が $1 \mu \mathrm{m}$ 以下での報告は少ないのが現状である4)。

複合材料の実用化には, 高強度で緻密な複合材料を製 造することが重要な課題であると考えられる。前報らで は, 筆者らが考案した加圧排気鋳造法により, 直径 $0.15 \mu \mathrm{m}$ の $\mathrm{Al}_{2} \mathrm{O}_{3}$ 粒子を用い, かつ $20 \% \sim 40 \%$ までの体 積率で空隙率が低い, 高強度の複合材料が得られた。し かしこの方法では空気の排出がまだ完全ではないと考兄 られる。
そこで本研究では, 加圧排気鋳造の際に溶湯の浸入段 階に扣いて加圧力をコントロールすることにより，溶湯 の補給方式をパルス状に加光, 空気の排出効率をあげ, 欠陷がより少なく機械的性質がより高い粒子分散強化複 合材料の作製を試みた。この方法を以下ではパルス加圧 排気鋳造と称する。また作製した $\mathrm{Al}_{2} \mathrm{O}_{3} / 6061$ アルミニ ウム合金複合材料の機械的性質を評価するとともに，こ の方法における溶湯の浸入過程拉よび組織の緻密化の成 因等を調べた。

\section{2. 実験方法}

本研究では，パルス加圧排気鋳造法を従来の加圧鋳造 および加圧排気鋳造の方法と比較するために, プリフォ 一ムとしての粒子充填方法, 押出条件, 空隙率測定方 法, 引張条件などの実験条件は前報らと同じようにし， また実験材料も同じ粒子とマトリクス合金を採用した。 すなわち, $\mathrm{Al}_{2} \mathrm{O}_{3} / 6061$ アルミニウム合金複合材料の作製 は，市販の平均直径 $0.15 \mu \mathrm{m}$ のアルミナ粒子および 6061 アルミニウム合金を用い，金型温度 $710 \sim 720^{\circ} \mathrm{C}$ ，溶湯 温度 $860 \sim 880^{\circ} \mathrm{C}$, 圧力 $73 \mathrm{MPa}$, ラムスピード0.5 0.6 $\mathrm{mm} / \mathrm{s}$ の条件で行った。

前報5)では，加圧鋳造の初期に加圧曲線に示す圧力は

* 軽金属学会第75回秋期大会（1988.11）で一部発表。

** 哈爾濱工業大学 (哈爾濱市)。Harbin Institute of Technology (Harbin-shi, China).

*** 千葉工業大学 (習志野市)。Chiba Institute of Technology (Narashino-shi, Chiba). 


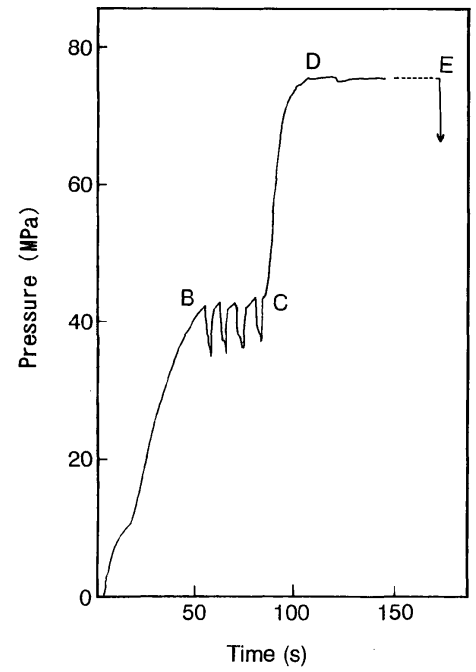

Fig. 1 Variation of applied pressure with time in pulse squeeze-exhaust casting.

急激に上昇するが, 臨界圧力になると溶湯がプリフォー ム中に浸入し始めるため, 圧力曲線の変化が緩やかにな り, 空気は主にこの段階で排出されることが明らかにな った。パルス加圧鋳造方法では，この空気の排出段階に おいて，プレスマシンのラムを降下一停止一降下一停止… 降下と 4 6 回繰返し作動して, 溶湯の浸入具合を調整 する。この場合, Fig. 1 に示すように加圧曲線の B-C 段階にパルス状の圧力変化が現れる。

また，溶湯浸入過程を知るために普通の加圧鋳造法と 加圧排気鋳造法およびパルス加圧排気鋳造法において, 溶湯の浸入途中で圧力を除き，金型を急冷した。この急 冷鋳塊の縦断面を浸透探傷凧で染色処理して複合途中の 試料のマクロ組織を観察した。

\section{3. 実験結果}

\section{1 パルス加圧方式による複合状態の改善}

Fig. 2 に示すのは, 浸透探傷剤で染色処理した $\mathrm{Al}_{2} \mathrm{O}_{3}$
粒子の体積率が30\%の急冷鋳塊縦断面のマクロ組織であ る。前報からわかるように，従来の加圧鋳造法の場合， 溶湯は加圧曲線の昇圧段階で金型の周りに沿って流込 み, 次第にプリフォームの中心方向へ浸入し, 空気をこ の中心部分に押し退ける。Fig. 2(a)では, 未複合の中 心部に向けて気孔群が帯状に分布しており，溶湯の浸入 状態を示している。

加圧排気鋳造法の場合，底面に排気口のある密閉され ていない金型を用いるため，溶湯は主に上から下へ浸入 すると同時に，空気を底面に押し退け，底部の排気口よ り大部分が排出される。Fig. 2(b)によると，残った空 気による気孔は帯状に分布しているが Fig. 2(a)より量 が少なく，かつ底部に向かっている。

一方，パルス加圧排気鋳造法で得られたマクロ組織を Fig. 2(c)に示すが, 帯状に分布している気孔がほとんど 認められなく, かつ溶湯は試料全体に浸入し, 均一な組 織となっている。

Fig. $3(\mathrm{a})(\mathrm{b})$ (c)には, Fig. 2 に示した $\mathrm{Al}_{2} \mathrm{O}_{3}$ の体積率 が $30 \%$ の鋳造方法の異なる 3 種の鋳造材の上部のミクロ 組織を示す。これによると, 従来の加圧鋳造法での組織 はFig. 3(a)に示すように粗くかつ部分的に複合してい ないと思われる大きな黒い欠陥の部分があり, 欠陷部の 直径が最大 $8 \mu \mathrm{m}$ のものもあった。一方, Fig. 3(b)の加 圧排気鋳造法で作製したものは欠陪が少なく，かつ 1 $\mu \mathrm{m}$ 以下と小さくほぼ均一な組織を示しており, さらに パルス加圧排気鋳造法で作製したものは Fig. 3(c)のと おり欠陥がさらに少なくなり極めて微細な組織を示し た。これより, 三つの方法で作製した複合材料の組織に は大きな違いがあることが明らかである。

\section{2 複合材料の空隙率および硬さ}

材料の緻密性を調べるために鋳造材の空隙率と室温の 硬さを測った。その結果を Fig. 4 に示す。図に示すよ らに空隙率は, 加圧鋳造に拈いては $\mathrm{Al}_{2} \mathrm{O}_{3}$ 粒子の体積率 が大きくなるにつれて $3 \%$ から $5 \%$ へと上昇する傾向を 示すが，加圧排気鋳造の場合は，いずれも $1 \%$ 程度とな

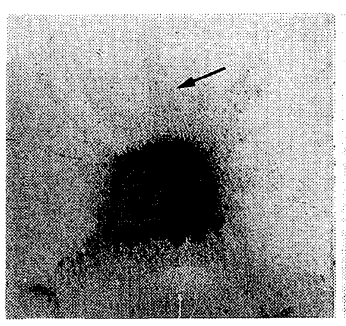

(a)

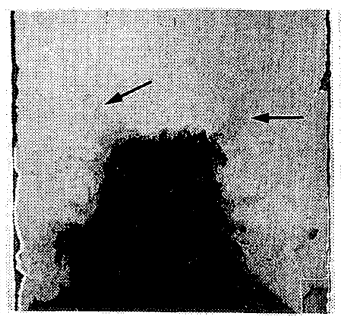

(b)

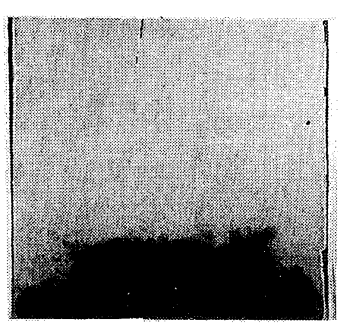

(c) $5 \mathrm{~mm}$

Fig. 2 Macrostructures in the time of composite processing of $\mathrm{Al}_{2} \mathrm{O}_{3} / 6061$ composite billet by various squeeze casting methods (volume fraction: $30 \%$ ). (a) squeeze casting (center), (b) squeeze-exhaust casting (bottom), (c) pulse squeeze-exhaust casting (bottom). 


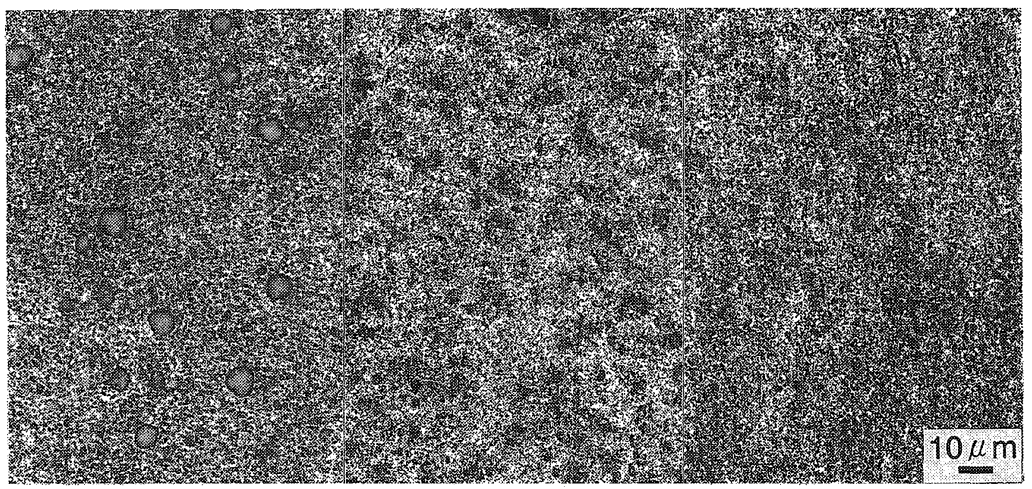

(a)

(b)

(c)

Fig. 3 Microstructures of as-cast $\mathrm{Al}_{2} \mathrm{O}_{3} / 6061$ composite materials by various squeeze casting methods (etched by $5 \%$ $\mathrm{NaOH}$ for $30 \mathrm{~s}$, volume fraction: $30 \%$ ). (a) squeeze casting, (b) squeeze-exhaust casting, (c) pulse squeeze-exhaust casting.

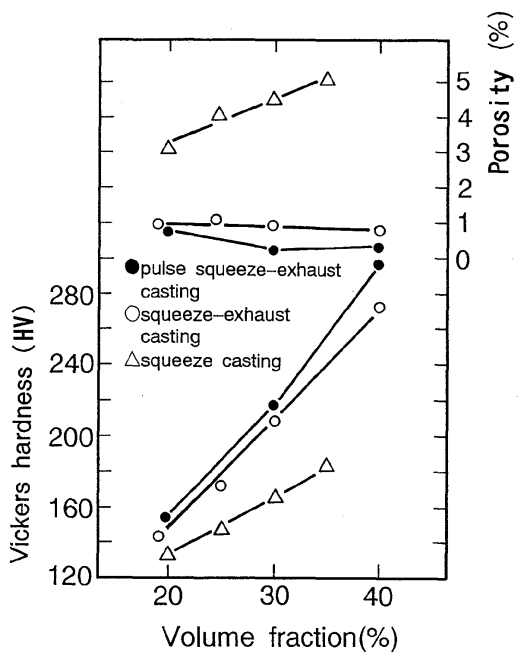

Fig. 4 Influence of volume fraction on porosity and hardness of as-cast $\mathrm{Al}_{2} \mathrm{O}_{3} / 6061$ composite materials.

り，さらにパルス加圧鋳造の場合は，それ以下の值とな って緻密性が増したことを示している。

また，パルス加圧排気鋳造では，硬さの変化が材料の 緻密性とよく対応し, 体積率が30\%の場合には, HV218になり，普通の加圧鋳造の HV163より大幅に上 昇した。またパルス加圧排気鋳造材の他の鋳造材との空 隙率と硬さの差は，いずれる $\mathrm{Al}_{2} \mathrm{O}_{3}$ 粒子の体積率が低い 場合では小さく，体積率が高くなると大になっている。 このことより, 複合化が困難とされている高体積率の場 合，パルス加圧の効果がより顕著に現れることがわかっ た。

\section{3 複合材料の引張強さおよび伸び}

Fig. 5 は, 各方法で作製した鋳造材の室温引張強さを 示す。四でわかるように，作製方法の違いとよって引張

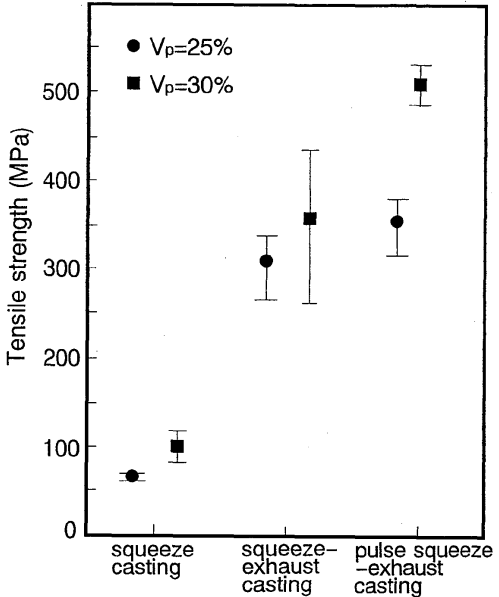

Fig. 5 Tensile strength of as-cast $\mathrm{Al}_{2} \mathrm{O}_{3} / 6061$ composite materials by various squeeze casting methods.

強さにかなり違いがある。体積率30\%の材料について は, 従来の加圧鋳造が $102 \mathrm{MPa}$ であるのに対して, 加 圧排気鋳造では $380 \mathrm{MPa}$ ，パルス加圧排気鋳造の方は $503 \mathrm{MPa}$ の值となり, 従来の加圧鋳造のむの上り強さ が 5 倍ほど向上したことが明らかになった。なおか゚ルス 加圧排気鋳造では，他の方法より体積率による引張強さ の差が顕著になっている。

Fig. 6 亿は, 体積率 $30 \%$ の押出材の高温引張試験結果 を示す。室温における引張強さは，従来の加圧鋳造の場 合412 MPa，加圧排気鋳造の場合は617 MPa，またパル ス加圧鋳造の場合は637 MPa の最高值を示していた。 いずれも温度の上昇とともに引張強さは低下し, $200^{\circ} \mathrm{C}$ では三つの方法で作製した材料はほ注等しい $274 \mathrm{MPa}$

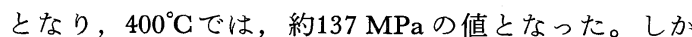




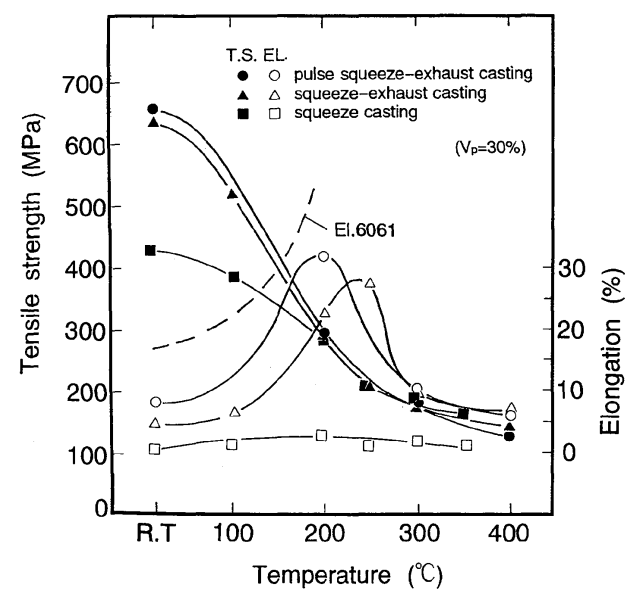

Fig. 6 Change of tensile strength (TS.) and elongation (EL.) with temperature for extruded $\mathrm{Al}_{2} \mathrm{O}_{3} /$ 6061 composite materials.

し, 伸びの值には大きな違いがみられ, 従来の加圧鋳造 したものの伸びはいずれの盜度でも $1 \%$ 程度にすぎない が，加圧排気材では室温で $5 \%, 200^{\circ} \mathrm{G} て ゙ は 22 \%$ とな り, たパルス加圧排気鋳造したものでは, 室温におけ

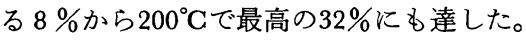

また，加圧排気およびパルス加圧排気鋳造した試料の 伸びが $250^{\circ} \mathrm{C}$ では温度の上昇とともに増加する傾向 は，図上に破線で示した6061合金の場合と大体同じ傾向 である。

\section{4. 考察}

\section{1 パルス加圧時の溶湯浸入過程}

パルス加圧排気鋳造法により材料の緻密性が向上する ことは, 溶湯の浸入と複合過程に関係があると考え，こ れを解析するために溶湯の浸入モデルを検討した。

Fig. 1 の加圧曲線に示すように, 溶湯の浸入段階でラ ムの降下をコントロールすることによって溶湯浸入の圧 力をパルス状に変える。ラム行程の進行または停止とい らことは, 溶湯の補給または停止のことを意味し, 加圧 曲線上に現れた圧力は, 注湯部における溶湯にかかって いる圧力であり，プリフォーム内に浸入した溶湯にかか っている圧力は, $\mathrm{Al}_{2} \mathrm{O}_{3}$ 粒子の表面張力および粒子間隙 からの流動抵抗により, 浸入深さの増加に従って急激に 減少し，溶湯浸入のフロントまでではほぼ零になると考 えられる6)。一般に，溶湯がプリフォーム中に浸入する と圧力損失が生じる。注湯部の圧力は, 外部加圧力と近 似できると考えれば，溶湯浸入帯部フロントの圧力は減 少し，粒子の表面張力とつり合っていると考える。

Fig. 7 に加圧鋳造（加圧排気鋳造を含め）とパルス加 圧排気鋳造の複合過程モデルを示す。Fig. 7(a) は溶湯
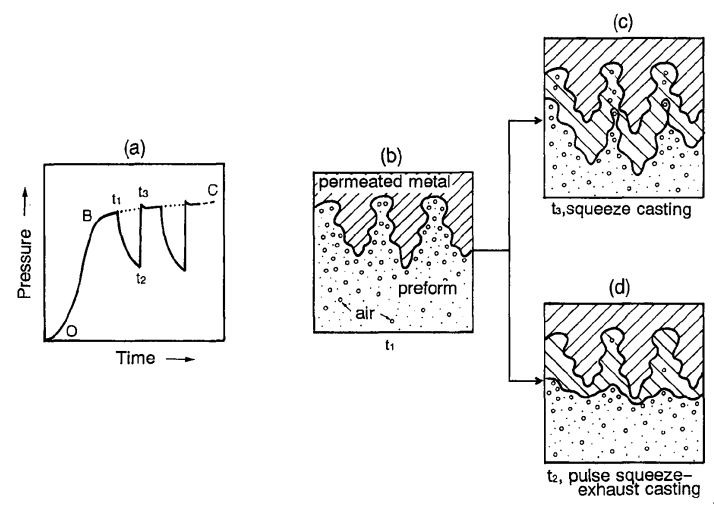

Fig. 7 Schematic explanation for permeation of molten metal.

浸入時の加圧曲線 B-C 段階の一部を拡大して示した。 この図で普通の加圧鋳造の加圧曲線は点線で, パルス加 圧鋳造の加圧曲線は実線で示した。Fig. 7 の（b）(c)（d) はそれぞれの時刻の溶湯の浸入状態の模式図である。

普通の加圧鋳造とパルス加圧排気鋳造による差異は, まず溶湯の補給方式, すなわち, 溶湯の連続補給と断続 補給との違いであり, 次に, プリフォームに浸入した溶 湯にかかっている圧力分布の変化, すなわち, 注湯部か ら浸入先端までの圧力勾配が一定であるか, それともそ の勾配が繰返し変化するかといらことであると考えられ る。

普通の加圧の場合, 時刻 $t_{1}$ では, 圧力が臨界圧力（B 点）を越えているので, 溶湯は粒子間の弱いところから プリフォーム内に優先的に浸入していき, かつ溶湯は連 続的に補給されるから, Fig. 7(b) に示すよ5に, いく つかの溶湯の “川”ができる。これらの“川” は長手方 向（金型の上部から下部へ）に延びる一方, 横にも広が る。しかし “川”内の溶湯の流動抵抗が小さく, また溶 湯が連続して補給されているので溶湯の長手方向への浸 入は速いと考えられる。このように, 溶湯はプリフォー ム内に長くかつ細い“川”をいくつも作るものと思われ る。この“川”の流れに伴って粒子間の空気を“川”の 前方と両側に押し退ける。“川”が成長して一定の幅に なる。 $t_{3}$ 時刻になると，隣接する“川”が合流し, Fig. 7 (c)に示すように“川”の両側に押し退けられて空気が 閉じ込められる。“川”が長いほど“川”と“川”の間 に残った空気が多くなり，そこが気孔の集合部となる。 そして，Fig. 2(a)（b)に観察されたように未複合部は中 心部または底部に向かい帯状の跡として残り，溶湯の流 れ経路を示すことになる。

加圧排気鋳造の場合では金型底面に排気口があるた め, 溶湯は主に上から下へ浸入していき，プリフォーム 中の空気は下へ押し退けられ，一部分が排気ロから排出 


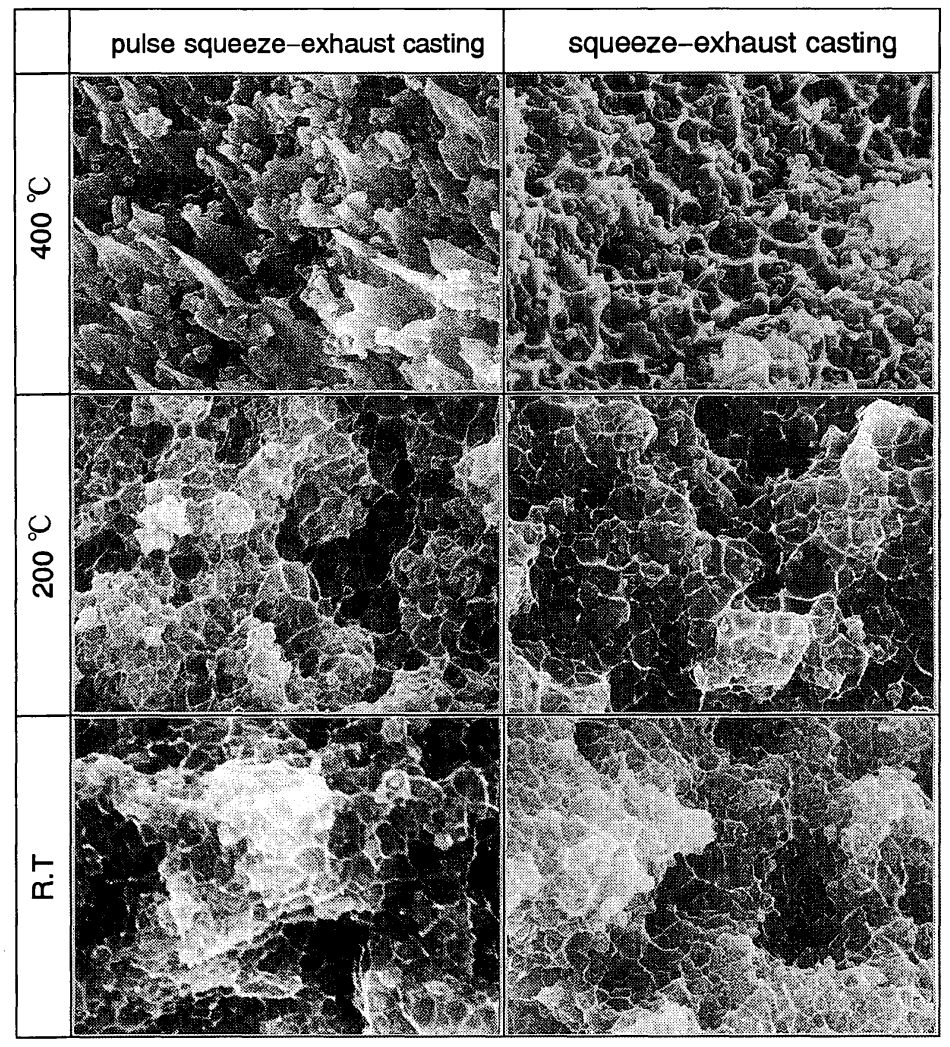

$1 \mu \mathrm{m}$

Fig. 8 SEM micrographs of tensile fracture surface of extruded $\mathrm{Al}_{2} \mathrm{O}_{3} / 6061$ composite materials.

されるようになるが気孔はまだ残り，底面に向からよう になったと考える。

一方，パルス加圧排気鋳造では， $t_{1}$ 時刻でラムの進行 を止める。この時点でも溶湯は残留圧力によってまたプ リフォーム中に浸入していくので，圧力曲線に現れた圧 力は緩やかに下がる。このラムの進行を止めた $t_{1} \sim t_{2}$ 間 では, “川”の基部の圧力が “川”の先端の圧力より大 なため, 先端部の進行は停止するが残留圧力により“川” はゆっくりと横に広がってお互いに合流し, プリフォー ム内の溶湯浸入部の前面はFig. 7(d) に示すょうに加圧 鋳造の場合より比較的平坦になる。そしてこの際 “川” の間にはさまれた空気の大部分は溶湯前面のプリフォー ム中に押しやられるものと思われる。その結果, Fig 2(c)に示すよらに“川”の間に閉じ込められた気泡は存 在しないかまたは極めて少なくなるのであろら。次に $t_{2}$ 〜 $t_{3}$ の加圧段階では, 圧力は急激に上昇する。その上昇 速度は加圧曲線上より $\mathrm{A}-\mathrm{B}$ 段階までの速度の約30倍と 推定される。このような急激な衝撃的加圧のため, Fig. 3 に示すよらな複合しにくい $\mathrm{Al}_{2} \mathrm{O}_{3}$ 粒子集団中にも 溶湯が浸入できると予想される。このことょり，Fig. 2(c)の写真に示したような“川”の痕跡が見えない緻密 な組織が形成されたものと考えられる。

\section{2 パルス加圧排気鋳造による $\mathrm{Al}_{2} \mathrm{O}_{3}$ 粒子/6061ア} ルミニウム合金複合材料の強さとじん性

以上の空隙率の測定, 組織の観察および溶湯浸入モデ ルなどの検討により，鋳造方法の違いによって，複合材 料の組織の緻密性に差異が生じ，このことより，材料の 機械的性質が異なることがわかった。

Fig. 8 には加圧排気鋳造とパルス加圧排気鋳造した押 出材の室温, $200,400^{\circ} \mathrm{C}$ の引張破断面の SEM 写真を示 す。破断面はいずれもディンプル状であり，6061合金母 相がこの複合材料に延性を付与していることがわかる。

加圧排気鋳造での試料では, 引張温度が $200^{\circ} \mathrm{C}$ ま゙上 昇しても破面の様子は室温のものと比べ汪とんど変化せ ず，ディンプルの底面には露出した $\mathrm{Al}_{2} \mathrm{O}_{3}$ 粒子が観察さ れた。

一方，パルス加圧排気鋳造で作製した試料では，室温

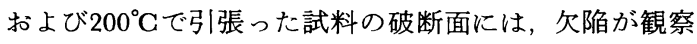
されず，ディンプル底面に露出した $\mathrm{Al}_{2} \mathrm{O}_{3}$ 粒子は加圧排 気鋳造のものよりさらに少なくなっており，パルス加圧 
によって粒子とマトリックスの結合はさらによくなって

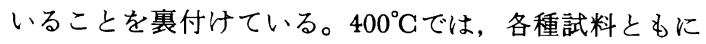
$\mathrm{Al}_{2} \mathrm{O}_{3}$ 粒子とマトリックスの界面が剥離され, 粒子の脱 落が多数観察された。

パルス加圧排気鋳造した複合材料について，各温度で 高い伸びを有することは, 気孔や未複合部などの欠陥が 少ない微細な組織によるためであり，また，伸びはマト リックス合金の塑性怙よび界面の結合状態にも関倸があ るものと考えられる。引張温度が高くなるにつれてマト リックスの塑性変形は容易になるが7)，一方ではマトリ ックスと粒子の界面の結合強度が下がる。ある温度（た とえば250ㄷ）までは，粒子とマトリックスの界面結合 強度がマトリックスの破断強度より高いため, 温度の上 昇とともにマトリックスの6061合金の塑性変形が起こり やすくなるとともに複合材料の伸びも高くなると考えら れる。引張温度が更にあがると, 界面の結合力が低下寸 るため, 低応力で界面が剝離し, マトリックスの塑性変 形がさらに起こりやすくなるにもかかわらず複合材料の 伸びは急激に低下すると考えられる。

また，300ㄷを越えた高温において，いずれの複合材 も引張強さと伸びは下がりほぼ同じ值になったのは，こ の条件の下で界面強度の劣化によって粒子の強化の役割 は失われたためであろら。この場合，試料の機械的性質 を左右するものは主にマトリックスとなる。したがっ て，排気による組織の緻密化による強化効果がなくな り，いずれの鋳造法で作製した複合材料ともほぼ同じ引 張強さと伸びとなったのであろう。

\section{5. 結言}

加圧排気鋳造において，溶湯の浸入段階にパルス状の
加圧を行うパルス加圧排気鋳造法を考案した。この方法 による $\mathrm{Al}_{2} \mathrm{O}_{3} / 6061$ アルミニウム合金粒子強化複合材料 の組織および機械的性質を検討した。その結果，次のこ とを明らかにした。

（1）パルス加圧排気鋳造によって未複合部のない極め て均一微細な組織の複合材料が得られた。

（2）パルス加圧排気鋳造により複合材料の引張強さは 向上し, $\mathrm{Al}_{2} \mathrm{O}_{3}$ 粒子体積率が $30 \%$ の場合，鋳造材では $500 \mathrm{MPa}$ の室温引張強さが得られ，押出材では室温で $637 \mathrm{MPa}, 200^{\circ} \mathrm{C} て ゙ は 274 \mathrm{MPa}$ の值となり，伸びは室温

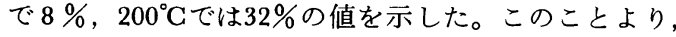
パルス加圧排気鋳造法により機械的性質が高くかつ延性 に優れた粒子強化複合材料が得られた。

（3）ハヘルス加圧排気鋳造による複合材料の機械的性 質, 特に伸びの向上は, 溶湯の浸入方式をコントロール することにより，空気の排出が十分に行われ，残留空気 による欠陥が減少し，かつ緻密な組織が得られたためで ある。

\section{参考文 献}

1）福永秀春：軽金属学会第76回春期大会講演概要集, (1989), 28.

2）小原嗣朗, 浅田修司：軽金属，37（1987），483.

3) E. Orowan: "Dislocations in Metals", AIME, 1954, p. 128 .

4) N. Izzat, E. S. Dwarakadasa, S. K. Goel and A. R. Ismail: J. Mater. Sci. Lett, 2 (1983), 750.

5）武 高輝, 河野紀雄, 渡辺久藤, 高橋恒夫 : 軽金属, 40 (1990), 176.

6）木内 学: 生産研究, 34 (1982), 179.

7）日本金属学会編：金属便覧，（1971）. 